\author{
CARIN FRANZÉN \\ Professor vid Institutionen för kultur och kommunikation, Linköpings universitet
}

\title{
UTOPISKA STRATEGIER I CHRISTINE DE PIZANS KVINNOSTADEN
}

\author{
UTOPIAN STRATEGIES IN CHRISTINE DE PIZAN'S CITY OF LADIES | Christine \\ de Pizan's appropriation of the dominant literary discourse in the later Middle Ages is an innovative \\ reworking of established models, especially that of the configuration of women in the two directions \\ of idealization and debasement. In the article I assess the strategies Christine develops to counteract \\ this dialectic in order to open a new - utopian - discursive space for female subjectivity. My examples \\ are mainly taken from Le Livre de la Cité des Dames (1404-1405). Late medieval representations \\ of women incorporate a radical change from the idealization of the Lady and love in courtly litera- \\ ture into a more explicit misogynistic configuration, which can be seen for example in Le Roman de \\ la Rose (c. 1230). I argue that Christine responds to this change by a disclosure of this ambiguous \\ discourse towards what it represses, i.e. a cultural unconscious of violent and incestuous dramas. \\ KEYWORDS | Christine de Pizan, Medieval literature, al- \\ legory, discourse analysis, psychoanalysis, gender.
}

Det har sagts att har man en gång tagit sig an Christine de Pizan blir man inte av med henne, man får henne på hjärnan, eller "under skinnet" som den engelsktalande säger. Så verkar det åtminstone vara för den stora mängd forskare som sedan några decennier tillbaka ägnar sig åt att läsa, fastställa, översätta och tolka de olika manuskript hon lämnat efter sig - ballader, berättande dikter, epistlar, historiekrönikor, pedagogiska handböcker, politiska skrifter och allegorier. Bara under de senaste tio åren har det skrivits fler än etthundrafemtion studier över hennes olika verk. De flesta av dem har blivit översatta till modern franska och engelska, det finns även ett internationellt Christine de Pizan-sällskap. Fenomenet vittnar om ett slags återupptäckt efter en lång period av glömska, vilket kan förklaras av det motstånd hon också väckt, tydligt uttryckt i Gustave Lansons beskrivning av henne i sin Histoire de la littérature française från 1894 som "en av de mest autentiska blåstrumporna som finns i vår litteratur, den första i en outhärdlig tradition av kvinnoförfattare" (I66-I67). Idag kan hon utan tvivel räknas till en av den medeltida litteraturens klarast lysande stjärnor, vilket också säger oss något om vår egen tid. Hennes historia, som inbegriper förflyttning över språk- och nationsgränser och en förunderliga intellektuell resa $i$ och genom en manlig hegemoni, äger oanad aktualitet.

Christine föddes I364 eller I365 (båda uppgifterna förekommer) och flyttade 
som helt ung från Italien till Frankrike när hennes far, Tommaso di Benvenuto da Pizzano, blev anställd som astrolog och livmedikus hos den franske kungen Karl V. Ibland kan man se hennes efternamn stavas med "s" men det lär bygga på en missuppfattning hos franska renässansförfattare som trodde att Christine kom från Pisa och inte från den lilla byn Pizzano utanför Bologna. Christine stavar hursomhelst alltid namnet med "z", vilket också har blivit det etablerade bruket bland dagens forskare.

Christine anses vara Frankrikes första kvinnliga professionella författare och hon inledde den banan när hon vid tjugofem års ålder blev änka och tvungen att ensam försörja sina tre barn samt sin mor. Själv har hon hävdat att det var tack vare poeternas muser, vilka gav henne tillfälle att dikta om sorgen över sin make, som hon började skriva. Ekonomisk nödvändighet var troligen en minst lika stor orsak. Tillgången till faderns och makens böcker, samt den tidigare närheten till det kungliga hovet, bidrog säkert också till att hon tog detta för en kvinna så ovanliga steg vid denna tid.

Med sitt skrivande intog Christine ganska snart en central plats i det franska kulturlivet under det slutande trettonhundratalet. Hon var först verksam vid Isabella av Bayerns och Karl VI:s hov, där den höviska koden gjorts till officiell moral och där man även bildat ett cour amoureuse, ett diskussionsforum för frågor om kärlekens natur och väsen som troligen även ledde till att man i en del fall omsatte teori i praktik. Det är i ett sådant sammanhang Christine skriver sina första verk. Till skillnad från föregångarna får Damen - den höviska diktningens objekt par excellence - tala själv i Christines dikter, och i hennes ofta ironiska turneringar av dess kärlekskod kan man urskilja en kritik av en manlig svekfullhet som troligen hade en direkt motsvarighet $i$ hovlivets intriger och dramer. Hon framhåller ofta de risker "kärlekshovet" medför för kvinnor i en manlig maktordning och uppmanar till omsorg om "det som ni framför allt måste försvara, det vill säga, er heder och ärbarhet och era dygders skönhet", som det senare skulle stå i hennes mest kända verk Kvinnostaden (le Livre de la Cité des Dames) från I404-I405 (304). I I det följande vill jag lyfta fram de strategier som Christine använder i sitt skrivande för att motverka misogynins effekter och lägga grunden till en kvinnlig subjektsposition inom en diskursiv ordning där hon hittills endast haft status som objekt.

\section{Approprieringen av den höviska diskursen}

Ett utmärkande drag i Christines kritik av misogynin i den medeltida litteraturen, och i synnerhet den som framträder i den andra delen av Romanen om rosen (Le Roman de la Rose) från cirka I230, kan förenklat kallas att ge svar på tal. Verket har liknats vid "en misogynins antologi, som omfattar en uttömmande katalog över författares och moralfilosofers samlade missnöjen sedan Ovidius och Juvenalis”

I I det följande anges först sidhänvisning till Kvinnostaden följt av en hänvisning till den franska originaltexten baserad på Richards utgåva 2004. Originalcitaten anges i noterna. 
(Strubel 27-28). Helen Solterer påpekar att Romanen om rosen utgjorde en medeltida "encyklopedi över kärleken och kvinnan" (I4). Man konsulterade den inte bara i filosofiska och moraliska frågor. I likhet med Ovidius Ars amatoria från cirka år I f. Kr. och Andreas Capellanus De amore från cirka II86 erbjöd den också praktisk kunskap om kärleken.

Den kritiska diskussion kring verkets misogyna aspekter som Christine initierar tar även upp Jean de Meuns intertexter. Ovidius kärlekskonst kallar hon i en av sina tidigare dikter, "Brev till kärleksguden” (Euvres poétiques I3) från I399, för en bok om "de stora svekens och det falska skenets konst". ${ }^{2}$ Den ironiska ton med vilken hon sedan beskriver klerkens allegori fångar inte bara hans många digressioner utan också och främst vad klerkens lärda diskurs om kärleken till syvende och sist handlar om:

"Och Jean de Meun eller Romanen om Rosen, Vilket omständligt företag! Vilken svår sak!

Både klar och dunkel kunskap

Har han infört där, och vådliga äventyr!

Och vilken mängd av folk han ber om råd

Och vilken möda och list han lägger ner

För att förleda en jungfru helt enkelt -

Det är målet, genom falskhet och slughet

Det krävs alltså massivt anfall på svag ort?

Hur kan man så nära ta sådan sats?

Det kan jag varken föreställa mig eller förstå.” (I3)3

Christines ifrågasättande av den etablerade kanonen och hennes initiativ till det som kallats Frankrikes första litterära debatt, må vara unika, men redan med sitt brev till Kärleksguden (och tidigare debattdikter) etablerar hon sig i en hovkultur där kvinnan sedan tidig medeltid haft en central plats i diskussionen om kvinnans och kärlekens natur och värde. Att det handlar om ordets makt i en mycket konkret bemärkelse visar det faktum att korrespondensen kring Romanen om rosen, som fått namnet "la querelle de la rose", från början tycks varit avsedd för hovets diskussioner. Christine sammanställde själv breven och dedicerade dem till Isabella av Bayern.

I polemiken med sin tids kulturelit är det uppenbart att Christine vänder sig mot den uppmaning till reproduktion som i de Meuns del framträder i den höviska kärlekens ställe. Där reduceras exempelvis kvinnan till ett medel, bildligt talat till en åker, för att försäkra släktets (och familjens) fortbestånd: ”Ploga, för Guds skull,

2 “[...] c'est livre d'Art de grant decevance, / Tel nom li don, et de fausse apparence”. När inget annat anges är översättningarna mina.

3 "Et Jehan de Meun ou Romant de la Rose, / Quel long procès! Quel difficile chose! / Et sciences et cleres et obscures / Y met il la et de grans aventures! / Et que de gent soupploiez et rovez / Et de peines et de baraz trouvez / Pour decepvoir sanz plus une pucelle, / S'en est la fin, par fraude et par cautelle! / A foible lieu faut il donc grant assult? / Comment peut on de près faire grant saut? / Je ne sçay pas ce veoir ne comprendre”. 
ploga herrar, / Och återställ er ätt! / Om ni inte verkligen tänker på att ploga, / Finns inget som kan återställa den" (IO22). ${ }^{4}$

Den höviska kärlekens omvandling till en mer materialistisk ideologi, som betonar reproduktionen, gagnar inte kvinnan i ett samhälle där hon redan är underkastad mannen. Den upphöjda och ouppnåeliga Damen är förvisso den nedvärderade kvinnobildens korrelat, men den utgör inte desto mindre ett positivt element som den kvinnliga mottagaren kan appropriera. Även om den höviska lyriken omvandlas till en uppsättning koder, moraliska figurer och psykologiska figurer, samt blir ett led i en ren förförelsestrategi, som handlar om att bemäktiga sig begärets objekt, kan dess diskurs hos en kvinnlig läsare, och a fortiori om hon skriver, vändas mot dem som infört den. Det är också den allegoriska erövringen av rosen i slutet av Jean de Meuns verk, vilken utförligt berättar om hur man våldför sig på en oskuld, som Christine både avvisar som omoralisk och själv ironiserar över: "Det krävs alltså massivt anfall på svag ort? / Hur kan man så nära ta sådan sats?" Med Foucault kan man säga att en sådan formulering inom diskursens ordning gör "våld på våldet" (IIO).

Det är rätt uppenbart att det inte är prydhet utan snarare just en analys av maktrelationer som utgör drivkraften i Christines kritik av Jean de Meun. Hans realism, som bland annat visar sig i verkets avvisande av den höviska kodens eufemismer till förmån för en direkt benämning av tingen uppenbarar en fallisk överhöghet: "Ty det är avsiktligt, och inte mot sin vilja, som Gud med en underbar intention har lagt generationens kraft i pungarna och pittarna för att släktet alltid ska hållas levande” (388). Den höviska kärlekens regler, som så noga räknas upp i den första delen av Romanen om rosen, reduceras i den andra till en sentimental och social konvention, men det som träder i dess ställe är, med Strubels formulering, "kampen om makten, maktförhållandena mellan könen, lurendrejeriet, lusten och egennyttan" (33). Det är en i lika hög grad diskursiv som social kamp, och den höviska idealiseringen av kvinnan och kärleken är inte bara till för att dölja eller kringgå den. Inom denna kamp blir idealiseringen ett element som ger kvinnan ett annat värde än som åker för kraften "i pungarna och pittarna".

I sitt övertagande av senmedeltidens dominerande diksurs om kvinnan och kärleken får Christine den höviska diskursen att fungera efter en annan vilja än den som framträder hos Jean de Meun, vilket jag vill exemplifiera genom att dröja vid Kvinnostaden. Allegorin har ofta uppfattats som ett avvisande av den medeltida misogynin och ett försvar för kvinnans värde och rättigheter, alltså som ett feministiskt verk. Den höviska kärleken utgör inte heller detta verks huvudtema, men idealiseringens figur är likväl central och används som ett argument mot den medeltida misogynin. Vad jag framför allt vill visa är hur Christine använder den för att underminera den dialektik som utgör den manliga föreställningen av kvinnan i den dominerande diskursen.

4 "Arez, pour Dieu, baron, arez, / Et vos lignage reparez! / Se ne pensez forment d'arer, / N'est riens qui les puist reparer". 


\section{Läsningens effekter}

I inledningen till Kvinnostaden befinner sig berättaren, som utan tvekan är Christine själv, i sin studerkammare. Hon har just lagt de vetenskapliga studierna åt sidan för att vila ut med poeternas dikter. Av en slump finner hon en liten bok som påstår sig vara skriven av Matheolus, och även om hon anser den vara "lättviktig" visar den sig exemplarisk även för de lärda böcker hon just läst. ${ }^{5}$

"Den [väckte] nu tanken hos mig att det var böcker som denna som var orsak till att så många män, både kyrkliga och lekmän, har varit och är benägna att $\mathrm{i}$ tal och skrift håna och förtala kvinnor och kvinnoting. Så sker inte bara i några få böcker, som Matheolus lättviktiga, närmast parodiska skrift, utan nästan alla författare och filosofer och poeter och storordiga talare, alltför många att räkna upp, tycks faktiskt tala med en enda röst, eniga om en enda sak, nämligen att det hör till kvinnans natur att vara hågad för och hemfallen åt alla slags laster" $(26 ; 42){ }^{6}$

I denna öppningsscen gestaltar Christine sitt möte med representationen av kvinnan i en medeltida litterär kanon, som hon sedan kommer att ifrågasätta utifrån sina egna erfarenheter, men även och framförallt ge en polemisk omtolkning. Hon använder sig av allegorin som ram och strukturerande princip, men hennes teknik är, som Blanchard påpekar, medvetet strategisk, hon syftar till att skriva en "kvinnlig läsares unika bok" (243).

I linje med den allegoriska traditionen sker själva övergången till det allegoriska förloppet genom en dröm, som signifikativt nog här omvandlats till ett melankoliskt tillstånd, vilket beskrivs på följande vis:

"Saken grep mig så djupt att jag till slut var som förlamad av obeslutsamhet. Under tiden for mängder av olika författares skrifter genom mitt huvud, som en brusande kaskad, den ena efter den andra. Till slut bestämde jag mig för att Gud måste ha gjort något avskyvärt när Han skapade kvinnan. [...] Medan jag så tänkte,

5 Christine refererar troligen till Jean Le Fèvres översättning (ca. I37I) av den latinska dikten, Liber lamentationum Matheoluli, skriven ca. 1295 av Mathieu de Boulogne. Enligt Bloch I99I är den "the most virulent antimatrimonial tract of the Middle Ages" (4).

6 "[...] pensant qu'elle peut estre la cause ne dont ce peut venir que tant de divers hommes, clercs et autres, ont esté et sont si enclins a dire de bouche et en leurs traictiez et escrips tant de deableries et de vituperes de femmes et de leurs condicions, et non mie seulement un ou.ij., ne cestui Matheolus, qui entre les livres n'a aucune reputacion et qui traicte en maniere de trufferie, mais generaument auques en tous traictiez, philosophes, poetes, tous orateurs desquieulx les noms dire seroit longue chose, semble que tous parlent par une mesme bouche et tous accordent une semblable conclusion, determinant les meurs femenins enclins et plains de tous les vices". 
överfölls jag av en modlöshet och sorg och kände förakt gentemot mig själv och hela kvinnokönet, som om vi var ett naturens missfoster." $(27 ; 44)^{7}$

Den huvudsakliga strategin för att motverka detta slags identifikation med den manliga nedvärderingen och dess medföljande självförakt är en figuration av idealiseringens rörelse - allegorin om en perfekt och ojämförlig stad. Byggandet av den tar sin början när de tre allegoriska kvinnogestalterna Fru Förnuft, Fru Rättrådighet och Fru Rättvisa väcker Christine ur hennes letargiska tillstånd och ger henne uppdraget att på "Litteraturens fält" skapa denna ideala stad som ska skydda från den aggressivitet och nedvärdering som uppenbaras när den höviska idealiseringen reduceras till en tom gest.

Kvinnostaden är uppbyggd som en kvinnokatalog, en uppräkning av historiska och mytologiska kvinnor, som till stor del återfinns i Boccaccios De claris mulieribus från cirka 1375 . Men originaliteten ligger i de strategier Christine utvecklar för att ge röst åt sin erfarenhet och tron på sitt eget köns värde genom en medveten omskrivning av den litterära traditionen. Tillvägagångssättet slås an redan i öppningsscenen.

Christine beskriver sig själv som en lärd kvinna, men hennes kunskap härrör från böcker där kvinnor får inkarnera "alla slags laster", som det står i det tidigare citatet. Det leder till ett tvivel på den egna betydelsen och till självförakt. När Jean de Meun lovsjunger reproduktionen och den manliga potensen vill Christine återge den kvinnliga berättaren (och läsaren) tron på sitt eget omdöme. Christines Raison säger att hon förblindats av den sorg och det självförakt misogynin framkallat, vilket fått henne att förkasta "allt som du säkert vet" och ansluta sig till en samling fördomar $(28 ; 48)$. Med Le Dœuff kan man säga att Christine i allegorins öppningsscen gestaltar "en diskontinuitet mellan kunskap och omdöme, mellan den intellektuella bildningen som kommer från studier och möjligheten att använda denna när den behövs som bäst” (224). Christine vet mycket väl att allt kan ifrågasättas, men hon är för ett ögonblick oförmögen att rikta sitt tvivel mot någonting annat än mot sig själv och sitt kön. Fru Förnufts första funktion blir här att befria henne ur det melankoliska tillståndet genom att uppmana henne att helt enkelt läsa på rätt sätt:

"Det verkar som om du tror att allt filosoferna säger är trosartiklar och att de inte kan ha fel. Och poeterna du talar om, du vet väl att de ofta uttrycker sig i bilder och ibland menar tvärt emot vad de säger? Antifras är den korrekta grammatiska termen, och som du vet ska en sådan förstås tvärt om, till exempel betyder 'den

7 "En ceste pensee fus tant et si longuement fort fichee que il sembloit que je feusse si comme personne en letargie. Et me venoient audevant moult grant foison d'aucteurs a ce propos que je ramentenoye en moy mesme l'un apres l'autres comme se ce feust une fontaine ressourdant. Et en conclusion de tout, je determinoie que ville chose fist Dieux quant il forma femme [...] Adonc moy estant en ceste pensee, me sourdi une grant desplaisance et tristece de couraige, en desprisant moy mesme et tous le sexe femmenin si comme se ce fus monstre en nature". 
där människan är ond' rakt motsatt 'hon är god'. Därför råder jag dig att vända deras ord om kvinnorna till din egen nytta och mening" $(29 ; 48){ }^{8}$

Som Solterer påpekat betraktades kvinnan under medeltiden som en mindre god läsare än mannen, oförmögen till någon annan tolkning än den rent bokstavliga (4). Här uppmanas Christine således att bevisa motsatsen inte bara genom att inta en kritisk och analyserande hållning till de filosofiska texterna utan också utnyttja den allegoriska tolkningens och den poetiska skriftens semantiska möjligheter. På så vis kan hon utifrån samma medeltida kanon som framkallade hennes melankoli producera "en imaginär stad befolkad av respektabla kvinnor, vilken utgör lika mycket ett psykologiskt stöd för läsaren, som en motståndets estetik och etik" (Le Dœuff 227).

Det diskursiva motstånd, som Christine bygger upp med sin arkitektoniska metaforik och omskrivning av den litterära traditionen, vilar likväl inte enbart på ett framhävande av den idealiserande polen i den rörelse som styr den förmoderna och patriarkala föreställningen av kvinnan. Den aggressivitet och maktkamp som förblir dold eller bortträngd i den höviska lyrikens idealiserade hållning och uppskjutande av begärets mål återkommer i Christines allegori i form av ett motstånd och ett självförsvar som kräver våld. Hennes rekonstruktion av den medeltida kvinnobilden innebär således inte ett enkelt återtagande av en hövisk norm. I de diskursiva relationer som iscensätts i Kvinnostaden kan man urskilja en specifik appropriering av den nedvärdering och idealisering som styr framställningen av kvinnan och kärleken i den medeltida litteraturen, eller med Lacans formulering, av "den sublimerande fantasins djupgående tvetydighet” (224). Jag vill nu mer i detalj precisera hur Christine utformar sin strategi för att hantera den medeltida misogynin.

\section{På skriftens slagfält}

Ett framträdande drag i Christines konstruktion av Kvinnostaden, som alltså utgörs av en omskrivning av andra författares kvinnobilder, är att hon ger legitimitet åt det som traditionen fördömer. Stadens första grundsten utgörs av den mytiska krigardrottningen Semiramis, som framställs som ett exempel på kvinnlig perversion hos auktoriteter som Boccaccio och Dante. Hos den senare finner vi henne vid sidan av Dido i helvetets andra krets, därför att "hon i lagen lät legitimera var form av otukt, för att själv ej tadlas" (Dante 32). Det hon med Dantes beskrivning på så vis söker skydda är den incestuösa relation hon har med sin son, vilken hon gift om sig med efter sin make Ninos död. I viss polemik mot sina föregångare

8 "Et il semble que tu cuides que toutes les paroles des philosophes soient article de foy et que ilz ne puissent errer. Et des poetes dont tu parles, ne scez tu pas bien que ilz ont parlé en plusieurs choses en maniere de fable et se veulent aucunefois entendre au contraire de ce que leurs diz demonstrent? Et les peut on prendre par une figure de grammaire qui se nomme antifrasis qui s'entent, si comme tu scez, si comme on diroit tel est mauvais, c'est a dire que il est bon, aussi a l'opposite. Si te conseille que tu faces ton prouffit de leurs dis et que l'entendes ainsi". 
ursäktar Christine Semiramis handling genom att låta Fru Förnuft förklara att hon levde under en tid då det inte fanns någon "skriven lag och människorna levde efter naturen" (65; I08). 9

Christines hänvisning till en tid före den skrivna lagen - som i en samtida kontext till stor del är identisk med den kristna läran - kan leda tankarna till Claude Lévi-Strauss antropologiska tes om incesttabut som civilisationens grundval, vilken har en uppenbar parallell i den psykoanalytiska teorin om oidipuskomplexet (563-564). Incesttabut markerar, enligt Lévi-Strauss, övergången mellan natur och kultur genom att det skulle framtvinga ett utbyte mellan grupper och därmed upprätta sociala band. I hans antropologiska undersökningar är det man utbyter alltid en kvinna - "mor, syster eller dotter" (552). Som Gayle Rubin påpekat i en klassisk artikel torde detta beteckna en specifik social ordning snarare än en tidlös och universell struktur. Lévi-Strauss beskriver, enligt Rubin, "ett system där kvinnor inte har full rätt till sig själva" (I77). Det är också en ordning som hon, förmodligen med rätta, menar existerar även i modern tid och anser nödvändigt att förändra. I linje med feminismens projekt uppmanar hon därför till en befrielse av "människans sexuella liv från de arkaiska relationer som deformerar det" (200).

I sin analys av Kvinnostaden bygger Maureen Quilligan vidare på Rubins artikel och hävdar att Christines presentation av Semiramis syftar till att befria det kvinnliga begäret från manligt förtryck genom att skapa en plats där "ingen skriven, manligt auktoriserad lag" begränsar hennes makt (8I). Quilligan menar vidare att Christine genom sitt försvar av den incestuösa Semiramis motsätter sig den oidipala kastrationsångest som den misogyna traditionen i grunden skulle drivas av:

"Christines företag skiljer sig från den manliga tradition som har sin upprinnelse i den manliga kroppens rädslor. Medan de [...] misogyna texter mot vilka hon skriver fann grunden för sin diskurs i berättade händelser som framhäver den ursprungliga kastrationsångesten, reviderar hon rätt skickligt betydelsen av problemet genom att säga att kastrationsångest helt enkelt inte gäller för kvinnor.” (8I)

För att tala med Lévi-Strauss kan man säga att Quilligans uppfattning om Kvinnostaden, som en plats där det kvinnliga begäret befriats från kastrationens begränsning, vittnar om en "gammal och varaktig dröm som uttrycker en bestående önskan om oordning, eller snarare motordning" (563). Man kan ju hävda att Kvinnostaden formulerar en "motordning" till medeltidens misogyna kultur, där kvinnan i allra högsta grad kan sägas cirkulera som en mer eller mindre värdefull vara bland män. Men samtidigt vill jag påstå att Christines strategi inte går ut på att befria sig från (manliga eller förtryckande) regler utan om att utnyttja dem för sina egna syften. Snarare än ett förkastande av en manlig tradition rör det sig om en appropriering, och om Kvinnostaden utgör en "alternativ tradition", vilket Quilligan hävdar (73), utgör den inte desto mindre ett element inom den förmoderna diskursens mångfald.

9 "[...] ancores point de loy escripte, ains vivoient les gens a loy de Nature". 
Om vi återgår till Christines förklaring av Semiramis beteende anges, förutom den mytiska tidsplaceringen, drottningens maktsträvan som ett huvudmotiv:

"Men skälen till hennes handlande var i huvudsak två: för det första, att hon inte ville att hennes rike skulle styras av någon annan drottning än hon själv, vilket hade varit fallet om hennes son hade gift sig med en annan kvinna; för det andra, att hon ansåg att ingen man var värdig att ta henne till hustru, annan än hennes egen son" (65; I08). .

Enligt Quilligan utgör detta slags kortslutning av den utbyteslogik, som garanterar sociala band enligt den strukturalistiska antropologin, en retorisk strategi i syfte att öppna upp ett diskursivt rum för kvinnor "utan hindrande gränser" (84).

Men hur är detta diskursiva rum egentligen beskaffat? Kvinnostaden har inte bara en incestuös moder som grundsten utan Guds moder som regent, vilket får den kvinnliga, moderliga makten att bli absolut. Dess rumslighet utgörs snarare av ett upprättande av gränser, det vill säga av en maktkonstruktion som skyddar mot den kastrationsångest (och melankoli) som omgivningens misogyni framkallar hos kvinnor. Allegorin utformar sig snarare till en omnipotent fantasi som belyser ett socialt och psykologiskt behov att motverka misogynin genom att vända idealiseringens andra sida, dvs. nedvärderingens drivkrafter, mot de härskande själva. Det skulle åtminstone förklara verkets många exempel av kvinnligt våld, där dödandet av mannen genom halshuggning är ett återkommande drag.

Efter den incestuösa Semiramis följer berättelsen om Amazonerna och krigardrottningen Tomyris, som enligt legenden besegrar den store Kyros. Hennes berättelse återfinns hos flera författare, och Christine har förmodligen hämtat den från Boccaccio eller Eustache Deschamps. Hennes beskrivning lyfter fram drottningens "omdöme, list och styrka", men också hennes grymhet och obönhörlighet. Den persiske storkonungen har dödat hennes son, och Christine framhåller henne som en hämnande moder:

"Stormande av vrede mot perserkonungen, eftersom en av hennes söner, som hon hade skickat till honom, hade blivit mördad, ville hon inte visa någon nåd, utan lät inför Kyros ögon hugga huvudet av alla hans stormän, och sade: Kyros, du som av grymhet har berusat dig på människoblod, här kan du dricka så mycket du vill. Strax lät hon hugga huvudet av honom och fick det kastat i ett vinkar som hon hade låtit fylla med stormännens blod" (68-69; II4)."

Io "Mais les causes qui la murent a ce faire furent.ij. principales: l'une qu'elle ne voulait mie que son empire eust autre dame couronne que elle, laquelle chose eust esté se son filz eust espoussee autre dame; l'autre estoit qu'il lui sembloit que nul autre homme n'estoit digne de l'avoir a femme fors son propre filz".

II "Pour la grant yre que elle avoit a lui pour un sien filz qui avoit esté occis, qu'envoyé avoit audevant de Cirus, ne le volt prendre a mercis, ains fist a tous ses barons trancher les testes devant lui, et puis apres lui dist: 'Cirus qui par ta crualté oncques ne fus saolé de sang d'ommes, or en peus boire a ta voulenté', et adonc sa teste, qu'elle ot faicte trancher, fist giter en une tine en laquelle avoit fait recueillir le sanc de ses barons". 
Fortsätter man att läsa i det psykoanalytiska perspektiv som initierats av Quilligan kan man i denna konstruktion av en kvinnlig auktoritet, och ytterligare grundsten till den perfekta staden, utan större svårighet urskilja just en kastrerande moder. Intrycket förstärks genom Christines återgivning av en annan legendarisk halshuggning, Judits bidrag till befrielsen av det Judiska folket från den assyriske förtryckaren Holofernes. Judit nämns i allegorins andra del som ett exempel på "allt det goda som sker i världen tack vare kvinnorna", och hon framställs i linje med den höviska och kristna kodens ideal, "en ädel och dygdig kvinna, som var ung och mycket vacker och därtill kysk och jungfru", vilket inte hindrar hennes dådkraft, tvärtom: "Utan rädsla tog hon svärdet som låg vid hans huvudgärd och drog det ur skidan och höjde det med all sin kraft och skilde hans huvud från kroppen utan att någon hörde något" (I78-I79; 300).12

Freud har intressant nog kommenterat just den legenden $i$ en artikel om "jungfrudomstabut" i olika kulturer. Han menar att den döljer en fientlighet mot mannen, som det fösta samlaget skulle väcka hos kvinnor, och härleder den affektiva reaktionen till kvinnans ovilja att lösa upp den oidipala - incestuösa - bindningen till fadern: Judits befrielse av det judiska folket kan således, enligt Freud, läsas som en symbolisering av "kvinnan som kastrerar mannen som hon har blivit deflorerad av" (223).

Holofornes deflorering av Judit nämns nu varken i bibeltexten eller av Christine, som kallar henne både för jungfru och la noble dame, men Freuds tolkning kan belysa komplexiteten i Christines strategi. Även om Freud, som Quilligan menar, misstar sociala omständigheter för psykiska betingelser, och kastrationsångest därmed inte skulle gälla för kvinnor, för Christine fram våldsamheten och fientligheten i kvinnornas hämnd på de manliga försyndelserna.

Om man vidare tar i beaktande att Christine aldrig ifrågasätter det kristna och höviska kyskhetsidealet i sin kritiska omskrivning av den dominerande diskursen blir det uppenbart att vi har att göra med en kvinnlig erfarenhet som ligger rätt långt från drömmen om sexuell frigörelse. I linje med den kristna traditionen tillskrivs jungfrun och det kvinnliga helgonet den högsta statusen $i$ en stad som regeras av Jungfru Maria: "För att hålla sällskap åt Himlens Drottning, Kvinnostadens välsignade härskarinna, måste vi ge plats i hennes närhet åt saliga jungfrur och heliga kvinnor" (26I; 434). ${ }^{13}$ Om något begär rör sig i detta diskursiva rum är det knappast för att det befriats från den manliga hegemonins gränser. Christines strategi syftar egentligen inte heller till att befria ett kvinnlig begär, hon pekar snarare på att allt begär är relaterat till maktrelationer. Vad hon däremot gör är att inom diskursens ordning underminera medeltidens misogyna kvinnobild genom att upphäva den dialektik av idealisering och nedvärdering som den drivs av.

I2 “[...] sanz paour prist l'espee qu'elle vid au chevet et la trait nue, puis la haulça de toute sa force et trancha a Olophernes la teste".

I3 "Pour faire compaigne al benoit Royne du Ciel, Empereris et Princesse de la Cité des Dames nous faut loger avec elle le benoit vierges et sainctes dames". 
Kvinnorna i den allegoriska staden är idealiserade, men det utesluter således inte passionerade och våldsamma handlingar. Monique Niederoest föreslår att detta våld syftar till att dekonstruera en manlig värld och erbjuda "kvinnor en möjlighet att lämna de etablerade föreställningarna om dem” (400). Det rör sig alldeles uppenbart om ett slags appropriering och till viss del dekonstruktion av dominerande kvinnofigurationer, men frågan är om det handlar om att lämna de etablerade föreställningarna. Genom att göra krigardrottningar till stadens grundstenar och överhuvudtaget lyfta fram affekter som aggressivitet, vrede och incestuösa begär, öppnas idealiseringen mot det som den nedvärderade kvinnobilden bygger på och själva den dialektiska rörelsen kortsluts. Christines specifika strategi "förutsätter passion" med Blanchards formulering (244). Men det är en passion som analyseras och används som motstånd, ja, motmakt mot det manliga begärets figurationer. Man kan också säga att hon låter förnuftet - omdömet - styra utan att det innebär en bortträngning av passionen och de imaginära möjligheter som den allegoriska diktningen skapar för att möjliggöra en kvinnlig subjektsposition.

\section{Christines passion}

Det hävdas ofta att Christines kritik av den medeltida misogynin har just den höviska kärleken som måltavla i synnerhet dess inbjudan till utomäktenskapliga relationer. Som Willard påpekar återkommer hon i sitt skrivande till "den otillåtna kärlekens faror och fåfänglighet” (364). Men Christines kritik bottnar inte bara i en moralisk hållning med kristna förtecken. På ett plan handlar den om den stora risk det innebär för en kvinna att bli sviken i sin kärlek men det är uppenbart att hon också vill framhålla kvinnan som en älskande. Hennes argument ingår i en diskurs som rör den i grunden höviska frågan om passionens intensitet, varaktighet och förädling. I den andra delen av Kvinnostaden låter Christine Fru Rättrådighet varna den kvinnliga läsaren att ge sig ut på "passionens farliga och förkastliga hav", men först efter att ha räknat upp ett flertal "historier om kvinnor som har älskat med dåraktig passion och ändå varit trogna till slutet” (242; 402). ${ }^{\mathrm{I}}$ De visar alla att även en dygdig kvinna kan älska, och Christine exemplifierar med bland annat Dido, Medea och Isolde. Likväl slutar alla dessa berättelser med död eller självmord, och används således både för att avvisa påståendet "att kvinnor när de en gång älskar skulle visa så lite kärlek", och som varnande exempel (227; 378).15 Med andra ord tycks det vara för att kvinnors passion är större och varar längre som de bör skydda sig från männens svekfullhet:

”Men dessa rörande exempel, och många andra som jag kunde berätta för dig, får inte vara anledning till att uppmuntra kvinnor att ge sig ut på passionens farliga och förkastliga hav, det slutar nämligen alltid illa och skadar dem till både kropp

4 "[...] des histoirs de femmes en tele fole amour surprises qui trop ont amé de grant amour sanz varier".

"[...] que femmes ne soient mie de si pou d'amour la ou leur cuer s'applique." 
och själ och egendom och heder. De kvinnor är kloka, som är förnuftiga nog att undvika detta och undviker att lyssna på männen som ständigt söker att bedra dem när det beger sig" $(242-243 ; 404){ }^{16}$

Jag vill hävda att det inte är ett avvisande av den höviska kärleken som står på spel i Christines polemik med den litterära traditionen. Det är sveket mot kvinnan och kärleken som utgör huvudskälet till hennes kritiska förhållningssätt. Man kan också säga att hon söker motverka idealiseringens obligatoriska övergång i nedvärdering genom att med mer eller mindre våldsamma medel hålla fast vid det värde som den höviska kärleken tillskriver kvinnan. Det motiveras av att det inte längre finns något försvar mot förtalet. Som hon skriver i början på sin allegori har kvinnorna sedan länge befunnit sig

"[...] oskyddade som $i$ en hage utan stängsel och utan någon försvarare som kan göra deras sak till sin, trots att många goda män av rätt och hävd borde ha försvarat dem, men i stället av försummelse och likgiltighet har tolererat att kvinnorna förtrampas. Då är det inte att förvånas över att deras avundsjuka fiender, med sina nesliga attacker och sina skurar av pilar, har vunnit striden mot de försvarslösa" $(32-33 ; 54) \cdot{ }^{17}$

Redan i denna beskrivning finns nyckeln till den huvudsakliga strategi Christine använder för att motverka misogynins effekter. Hon vänder den aggressiva - krigiska - maktretoriken mot dem som infört den och omvandlar på så vis den kluvna representationen av kvinnan till en mer komplex representation. Eftersom de "goda" männen, les nobles hommes, svikit och nedvärderingen fått fritt spelrum lyfter hon fram ett kvinnligt våld som sin stads grundval, men också som en genomgående princip i konstruerandet av den.

Christine öppnar alltså idealiseringen mot dess bortträngda sidor, de aggressiva dimensioner som representationen av kvinnan och kärleken bär på i den medeltida traditionen, vilka kommer till uttryck i kyrkofädernas misogyni liksom i den höviska kodens genomgående omslag i satir och kontrakod. Hon omvandlar maktretoriken till en del av det skydd som ska försvara mot fiendernas "nesliga attacker". Detta är kanske att underblåsa antagonismen mellan könen, men det är också ett konstruktivt drag för att motverka den melankoli kvinnan förvisas till av

I6 "Mais ces piteux exemples, et assez d'autres que dire te pourroie, ne doivent mie estre cause d'esmouvoir les courages des femmes de eulx ficher en celle mer tres perilleuse et dampnable de fole amour, car tousjours en est la fin a leur grant prejudice et grief en corps, en biens et en honneur et a l'ame. Qui plus est, si feront que sages celle qui par bon sens la saront eschever et non donner audience a ceulx qui sanz cesser se traveillent d'elles decevoir en tel cas".

I7 "[...] delaissees, descloses comme champ sanz haye, sanz trouver champion aucun qui pour leur deffence comparust souffisemment, nonobstant les nobles hommes qui par ordenance de droit deffendre les deussent, qui par negligence et nonchaloir les ont souffertes fouler, par quoy n'est merveille se leur envieux ennemis et l'outrage des villains, qui par divers dars les ont assaillies, ont eu contre elles victoire de leur guerre par faulte de deffence". 
misogynin. På så vis kan hon också uppmana alla kvinnor i slutet av sin allegori att glädjas:

”Dessutom, mina kära damer, är det naturligt för människohjärtan att glädjas åt framgång i ett företag där fienden har övervunnits. Ni har nu skäl, mina kära, att i ärbarhet och gudsfruktan glädja er åt att ha sett den nya Staden fullbordas, den som ska tjäna inte bara till beskydd åt alla som älskar dygden, utan också som ert försvar mot era fiender och angripare, om ni vaktar den väl" (30I-302; 498). ${ }^{18}$

I detta avslutande kapitel i allegorin vänder sig Christine direkt till sina läsare och åhörare, och deklarerar att den "den nya Staden" konstruerats för alla kvinnor, "såväl de från förr som de närvarande och de efterkommande" (30I; 496). ${ }^{19}$ Allegorins utformar sig på så vis till en vision som lyder förnuftets snarare än förtalets eller den poetiska musans röst, och där objektet för den höviska såväl som den ohöviska litteraturens inspiration - kvinnan - förankras i en konkret, politisk och social erfarenhet, men framför allt själv har ordet i sin makt. Den känslointensitet joi - som en gång drev trubadurernas kärlekssånger återkommer i ett passionerat skrivande där kvinnans värde återupprättas. Och det gäller "såväl de från förr som de närvarande och de efterkommande".

I Kvinnostaden förenas tidens kristna och höviska dygder med ett genusperspektiv. Den ideala staden är förvisso en fantasivärld - ett "ingenstans" - omgärdat av ett konditionalt modus. Här får endast de kvinnor leva som "vaktar den väl", det vill säga förblir ärbara och gudfruktiga. Likväl har denna stad en motsvarighet i tidens sociala verklighet som går utöver dessa konventionella ramar. Som Kristeva påpekat råder en analogi mellan den medeltida kulten av Maria Regina och den feodala adelsdamens makt (307). Och Christine utnyttjar den väl för att återupprätta kvinnans värde. På så sätt uppenbarar hon att en politisk maktkamp kan föras diskursivt, som en symbolisk och estetisk strid. Om den kampen i något avgörande avseende ändrade maktförhållandena mellan könen i det medeltida samhället låter jag vara osagt, men verket visar att diskursens ordning är instabil, att den kan störas, skrivas om och förändras. Det är och förblir dess utopiska potential.

I8 "Et mes tres cheres dames, chose naturelle est a cuer humain de soy esjouyr quant il se treuve avoir victoire d'aucune emprise, et que ses ennemis soient confondus. Si avez cause orendroit, mes dames de vous esjouyr vertueusement en ieu et bones meurs par ceste nouvelle Cité veoir parfaicte, qui peut estre non mie seulement le refuge de vous toutes, c'est a entendre des vertueuses, mais aussi la deffence et garde contre voz ennemis et assaillans, se bien la gardez".

I9 "[...] tant les passees dames, comme les presentes et celles a avenir". 


\section{LITTERATURLISTA}

Blanchard, Joël. "Compilation and Legitimation in the Fifteenth Century: Le Livre de la Cité des Dames”. Reinterpreting Christine de Pizan. Red. Earl Jeffrey Richards. Athens, GA: University of Georgia Press, 1992.

Bloch, R. Howard. Medieval Misogyny and the Invention of Western Romantic Love. Chicago: Univ. of Chicago Press, I99I.

Christine de Pizan. Kvinnostaden. Övers. Jens Nordenhök. Stockholm: Ersatz, 2012.

Christine de Pizan. La Città delle Dame. Red. Earl Jeffrey Richards. Rom: Carocci, 2004.

Christine de Pizan. Euvres poétiques II, utg. Maurice Roy, Paris I886

Dante. Den gudomliga komedin. Övers. Ingvar Björkeson. Stockholm: Natur och Kultur, I983.

Foucault, Michel. "Nietzsche, genealogin, historien”. Diskursernas kamp. Övers. Lars Bjurman. Red.

Thomas Götselius och Ulf Olsson. Stockholm: Brutus Östlings Bokförlag Symposion, 2008.

Freud, Sigmund. Samlade skrifter V. Övers. Ingrid Wikén Bonde. Red. Clarence Crafoord, Lars Sjögren och Bengt Warren. Stockholm: Natur och Kultur, 1998.

Guillaume de Lorris och Jean de Meun. Le Roman de la Rose. Utg. Armand Strubel, Paris: Le Livre de Poche, I992.

Kristeva, Julia. Histoires d'amour, Paris: Denoël, I983.

Lacan, Jacques. Psykoanalysens etik. Sjunde seminariet 1959-60. Övers. Zagorka Zivkovic och Jurgen

Reeder. Stockholm: Natur och Kultur, 2000.

Lanson, Gustave. Histoire de la littérature française. Paris: Hachette, 1952.

Le Dœuff, Michèle. Le sexe du savoir. Paris: Flammarion, 2000.

Lévi-Strauss, Claude. Les structures élémentaires de la parenté. Paris: Mouton, 1967.

Niederoest, Monique. "Violence et autorité dans la Cité des Dames". Au champ des escriptures. III" Colloque international sur Christne de Pizan. Red. Eric Hicks. Paris: Champion, 2002.

Quilligan, Maureen. The Allegory of Female Authority. Ithaca: Cornell Univ. Press, I99I.

Richards, Earl Jeffrey. “Christine, Courtly Diction, and Italian Humansim”. Reinterpreting Christine de Pizan. Red. Earl Jeffrey Richards. Athens, GA: University of Georgia Press, I992.

Rubin, Gayle. "The Traffic in Women: Notes on the 'Political Economy' of Sex". Toward an Anthropology of Women. Red. Rayna R. Reiter. New York: Monthly Review Press 1975.

Solterer, Helen. The Master and Minerva. Disputing Women in French Medieval Culture. Berkeley: University of California Press, I995.

Willard, Charity Cannon. "Christine de Pizan's Cent Ballades d'Amant et de Dame”. Court and Poet. Red. Glyn S. Burgess. Liverpool: Francis Cairns, I98I. 